\title{
The Effect of Billboards on Turnout in 4 States: A Randomized Experiment
}

\author{
Scott L. Minkoff \\ Associate Professor \\ Department of Political Science and International Relations \\ SUNY New Paltz
}

\section{Christopher B. Mann}

Assistant Professor

Department of Political Science

Skidmore College

\begin{abstract}
This paper presents the design and results of a voter mobilization field-experiment conducted during the 2019 election in conjunction with Vote.org. To test the effect of non-partisan voter mobilization billboards fitted with Election Day information, maps of study areas in four states were overlaid with a grid (or "fishnet") containing 3-mile by 3-mile cells. Cells were randomly selected to be in the treatment or control group. All available billboards in the treatment cells that met certain criteria were purchased and fitted with a reminder to vote. Across the four states, 207 billboards were treated and 142 served as control billboards for the weeks leading up to Election Day. Results indicated that registered voters living in treated cells had a probability of voting that was higher than those living in control cells. The effect size was similar in magnitude to comparable mobilization treatments and was strongest among mid-propensity voters.
\end{abstract}

Paper prepared for the 2020 Annual Meeting of the American Political Science Association, September 10-13. 
During the 2010 Wisconsin gubernatorial election between Scott Walker (R) and Tom Barrett (D), Republican activists ran a 75-billboard campaign concentrated in the Milwaukee area (Pabst 2010). The billboards featured three people behind prison bars (two Black, one white) with one saying, "We Voted Illegally" and a large message at the top that read, "Voter Fraud is a Felony." One of the funders of the campaign was the conservative Bradley Foundation, whose CEO, Michael Grebe, was also chairman of the Walker campaign. While Grebe said the billboards had nothing to do with the Walker campaign, they were a transparent attempt to suppress voter turnout in areas with large concentrations of Democratic voters (Bice 2012).

We don't know if these efforts worked. What we do know is that in 2018, the nonpartisan voter registration and mobilization organization Vote.org began taking a different approach to campaign billboards. Instead of using billboards to suppress turnout, they decided to use them to increase it. For that cycle, Vote.org bought over 2,500 billboards and other transportation related signs (e.g. bus banners) in Arizona, Texas, Wisconsin, Florida, Tennessee, Mississippi, Ohio, Michigan and North Carolina with a simple message: Vote on Election Day (Bowman 2018; Vote.org 2018). In keeping with the organization's mission, billboard purchasing emphasized areas with historically low turnout.

Following the 2018 billboard campaign, we conducted a post-hoc proximity-based study of sign effectiveness for the billboards purchased in Arizona and Mississippi. The results of that study were promising if very preliminary: mid-propensity voters that lived closer to billboards were more likely to have voted than similar voters that lived farther away (Minkoff 2019). For the 2019 election cycle, we designed a field-experiment aimed at testing the effectiveness of Vote.org's billboard campaigns in Mississippi, Louisiana, Virginia, and Kentucky. This paper presents the development and results of that experiment. Given the research design challenges and the dearth of prior studies, our findings should not be read as conclusive. Nevertheless, the overall picture presented is one that suggests that billboards have a positive effect comparable to other voter mobilization advertisements. And while billboard costs are a function of several variables, they may present an opportunity for efficient voter mobilization advertising in areas with historically low turnout levels. 


\section{Mobilizing Voters}

Whether large-scale voter mobilization campaigns are effective is a question being asked by a lot of people who are getting a lot of different answers. Given the diversity of political contexts, political strategies, and even research designs, this is hardly surprising. For example, Krasno and Green (2008) found only a negligible effect for television advertisements in their study of the 2000 presidential campaign. However, Green and Vavreck (2006) found that nonpartisan "Rock the Vote" television advertisements were effective at increasing turnout among younger voters in 2004. Nevertheless, the totality of the evidence points to well-produced mobilization campaigns having a positive effect on turnout, even if those effects are relatively small. A meta-analysis of over 200 studies by Green et al. (2013) found that tactics such as direct mail, door-to-door canvasing, and phone calls can increase the probability of turnout between 0.4 and 1.0 percentage points. More recently, several studies have looked at the effectiveness of direct text-messaging (SMS) on voter mobilization and found evidence of effects in this range (Bergh, Christensen, and Matland 2019; Bhatti, Dahlgaard, and Hansen 2017; Mann and Haenschen 2019).

We are aware of only one published study of the effect of billboards on voter turnout. Panagopoulos and $\mathrm{Ha}$ (2015) ran a matched-group field experiment using billboards encouraging turnout in 2007 mayoral elections in northeastern American towns. They created three groups of eight towns, each of which was balanced along demographic and political dimensions, and randomly selected one from each group for the billboard treatment. In each treatment town, enough billboards were purchased to reach about $25 \%$ of the population. They did not find a significant turnout effect for the billboards.

\section{Billboard Marketing}

Of relevance is also the research on billboard marketing effectiveness. We suspect that a considerable amount of this research is proprietary and thus inaccessible. There are, however, a limited number of published studies. These studies utilize two methodologies. The first is surveying consumers to see if people who ultimately purchased the product or service being offered were aware of the billboard advertisement (Fortenberry Jr, Elrod, and McGoldrick 2010; Papas, Logan, and Tomar 2004). Of course, such analyses are typically restricted only to those who purchased the product or service, eliminating the 
possibility of understanding the people who saw the billboard but did not act as a result of it. The second method involves pre/post-test analyses that examine elasticities in purchasing patterns (Frison et al. 2014). In general, these studies show a range of effectiveness based on product and strategy.

Neither of these designes is particularly appropriate for examining whether billboards mobilize voters. While a population could be surveyed to see if they saw a billboard and voted, the survey would need to be very narrowly targeted and the number of people who both saw a billboard and responded could be too low to draw inferences from. And simply comparing voting rates before and after the billboard placement is difficult in an environment where the product (voting) is primarily "purchased" on a single day. Evaluating the effectiveness of billboards on voting requires an alternative approach.

\section{Hypotheses}

Based on prior research and expectations about the function of the billboard program, we test four straight-forward hypotheses of voter mobilization:

Hypothesis 1: Registered voters exposed to a treatment billboard will be more likely to turnout than registered voters exposed to a control, all else being equal.

Hypothesis 2: The effect of the treatment will be larger for middle-propensity registered voters than will be for low or high-propensity voters, all else being equal.

Hypothesis 3: Conditional on treatment exposure, registered voters exposed to more treatment billboards (higher dosage) will be more likely to turnout than registered voters exposed to fewer treatment billboards (lower dosage), all else being equal.

Hypothesis 4: Conditional on treatment exposure, registered voters that reside closer to a treatment billboard will be more likely to turnout than registered voters who live farther from a treatment billboard, all else being equal.

Like any voter mobilization effort, billboards exist in a variety of electoral contexts (national, state, and local) that impact turnout to varying degrees. The question of how effective billboards are at improving turnout is conditioned by these various contexts, including all the other voter mobilization efforts that may be going on in the election.

\section{Research Design}

Gauging the effectiveness of billboards on turnout presents a variety of empirical challenges. 
Foremost among those challenges is that it is difficult to know who is actually exposed to a billboard and who is not. Relatedly, a person's exposure location and voting location are frequently not the same because billboards are viewed by people in vehicles as they travel - the effect of a billboard is not constrained to the space immediately around the billboard. While these challenges can be partially overcome with careful research design, they remain critical limiting factors. In this section, we review the approach we took to in a non-experimental 2018 study and discuss how it informed the development of the 2019 field-experiment.

\section{The 2018 Vote.org Study}

For the post-election non-experimental analysis of Vote.org's 2018 billboard campaign, a proximity strategy was used. With that study, distance to a billboard proxied for exposure such that the hypothesis was that those who live closer to billboards would be more likely to turnout. That approach had some inherent problems. First, a considerable portion of the billboards purchased by Vote.org were along highways that route through more urban and suburban areas. Those living near these highway billboards (by road or as-the-crow-flies) may not actually be the people who are regularly exposed to it. Consider the image in Figure 1 below, which shows one of Vote.org's 2018 Maricopa County, AZ billboard purchases. The billboard is located along West Maricopa Freeway but is primarily viewed from Route 60 (see inset). There are a considerable number of homes in this Central City South neighborhood that are spatially proximate to the billboard but the people who live in these homes are not be the people most likely to see it. Indeed, the people who live closest to this billboard would need to travel to the closest highway exit and head in the direction of the billboard to see it. Meanwhile, people traveling from farther away may pass it every day on their commute.

To deal with this problem, we made a distinction between a "full effect" and an "observable effect." Any person that passes by a billboard may be reminded of when Election Day is and, as a result, vote (or not vote) - capturing this would amount to identifying the full effect. Absent the ability to track every person's actual exposure and turnout, we could not measure the full effect of the billboards. Instead, we focused on identifying what we call a "spatially proximate observable effect" (SPOE). SPOE is the idea that owing to their geographic location, some billboards will have an observable effect on voters 
that live nearby and some will not. Highway billboards are not likely to have a substantial SPOE for the reasons outlined above. A spatially proximate observable effect is more likely if the billboard is situated in a place where the people who live close to the billboard are also the people who are most likely to see it. These billboards tend to be the ones in commercial areas that have adjacent residential areas.

Consequently, for the 2018 analysis we coded all billboards based on the likelihood they would have an SPOE and constrained the proximity analysis to strictly those billboards. Ultimately, that analysis found that mid-propensity voters living within 1-mile of a billboard were between and 1 and 2.5 percent more likely to have voted than similar voters living 9-10 miles away from a billboard. We found a very weak or no effect for low and high-propensity voters.

\section{Figure 1. Highway Billboard Example}

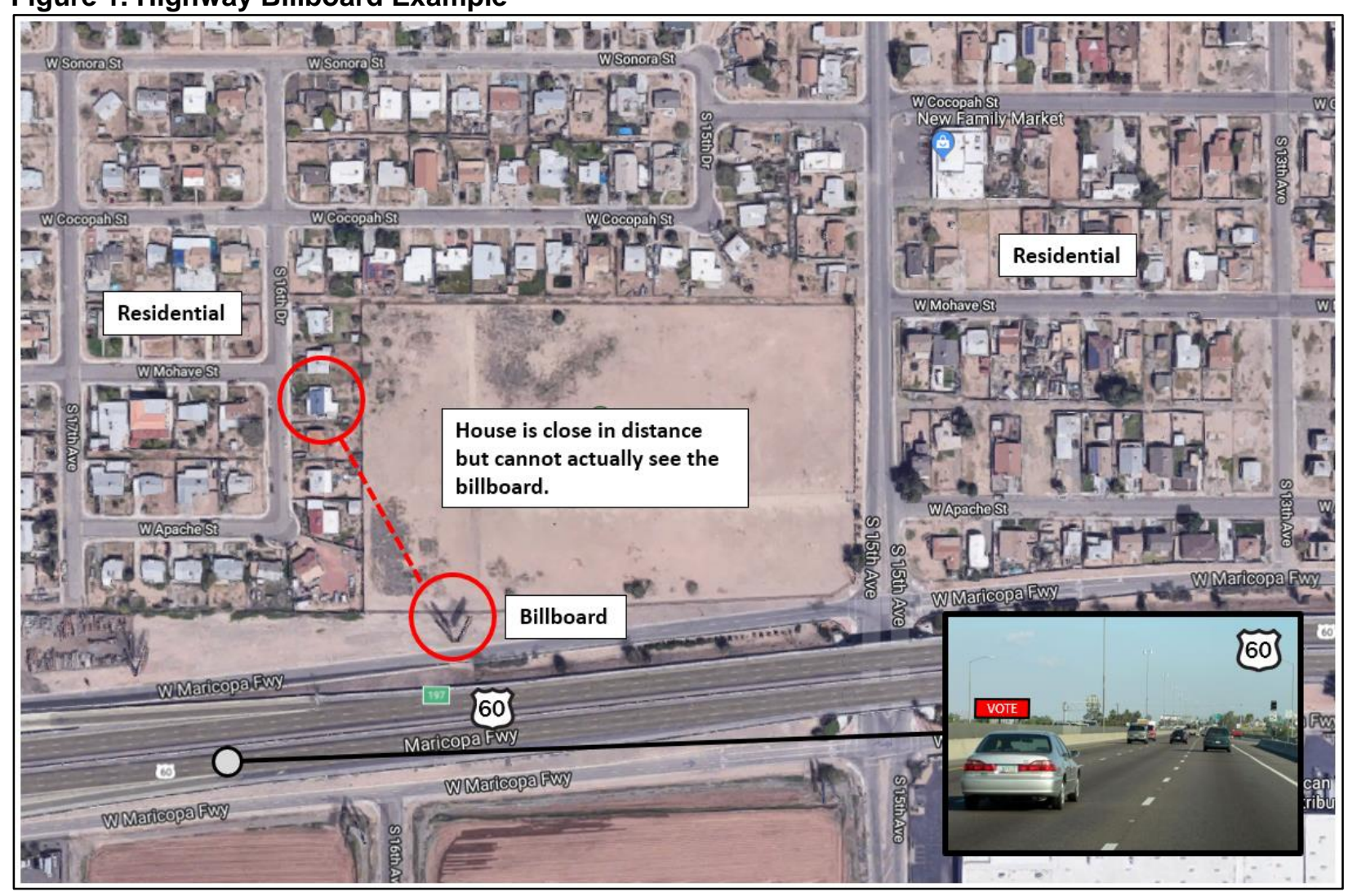

\section{The 2019 Vote.org Study}

The development of the 2019 research design commenced prior to the purchasing of the billboards. This time the approach was to utilize a field-experiment that would allow for stronger (if still 
limited) causal inferences. Working with Vote.org and the billboard vendor, we obtained a list of billboards that was roughly twice the size of Vote.org's budget, met Vote.org's criteria of emphasizing areas with historically lower turnout, and our SPOE criteria. ${ }^{1}$ The four study areas included Louisiana, Mississippi, and parts of Virginia (the Norfolk and Richmond areas) and Kentucky (Louisville). See Table 1 for a list of 2019 elections in each state.

Table 1. Elections in Each State

Numbers in parentheses indicate the number of elections held across the entire state.

\begin{tabular}{l|l}
\hline Site & Elections \\
\hline Louisiana & $\begin{array}{l}\text { Governor, Secretary of State, State Treasurer, Commissioner of Agriculture and Forestry, } \\
\text { Commissioner of Insurance, State House of Representatives (105), Selected State Senate (39) }\end{array}$ \\
\hline Mississippi & $\begin{array}{l}\text { Governor, Lieutenant Governor, Secretary of State, Public Service Commissioner (3), Agriculture } \\
\text { Commissioner, Insurance Commissioner, Auditor, Treasurer, Transportation Commissioner (3), } \\
\text { State House of Representatives (122), State Senate (52) }\end{array}$ \\
\hline Virginia & State House of Delegates (100), Selected State Senate (40) \\
\hline Kentucky & $\begin{array}{l}\text { Governor, Lieutenant Governor, Attorney General, Secretary of State, Agriculture Commissioner, } \\
\text { Auditor, Treasurer, State Supreme Court, State Intermediate Appellate Court (2) }\end{array}$ \\
\hline
\end{tabular}

The random assignment strategy involved laying a grid - known as a "fishnet" - over a map of each of the four research areas. Each fishnet had cells that were 3-miles by 3-miles and had a random starting point so as to create equally sized geographic boundaries that were independent of existing geographic boundaries. Fishnet cells were then randomly assigned to be treatment cells or control cells. Any proposed billboard in a treatment cell was then purchased from the vendor while billboards in control cells were left un-purchased (meaning they could be purchased by any other entity for any purpose). ${ }^{2}$

Treated billboards were non-partisan voting reminders that contained the word "vote" and the relevant voting day (see Figure 2). They also had "Vote.org" or the Vote.org logo on them. This assignment strategy is visualized for Virginia in Figure 3. The map shows the fishnet laid over the state with cells shaded to indicate whether they were randomly assigned the treatment condition (gray) or the control condition (white). The dots represent the full list of potential billboards presented to Vote.org for

\footnotetext{
${ }^{1}$ In practice, this meant billboards that were not located on major highways.

${ }^{2}$ A preferable strategy would have been to provide all of the control billboards with a sign unrelated to billboards (e.g. encouraging blood donations, volunteering, or another public good), but budget constraints prevented this.
} 
purchase. All billboards that fell into a gray treatment cell were purchased (colored green here) while the billboards in the white cells were not purchased (colored red here). The same process was used for each of the for research areas.

\section{Figure 2. Vote.org Billboards}
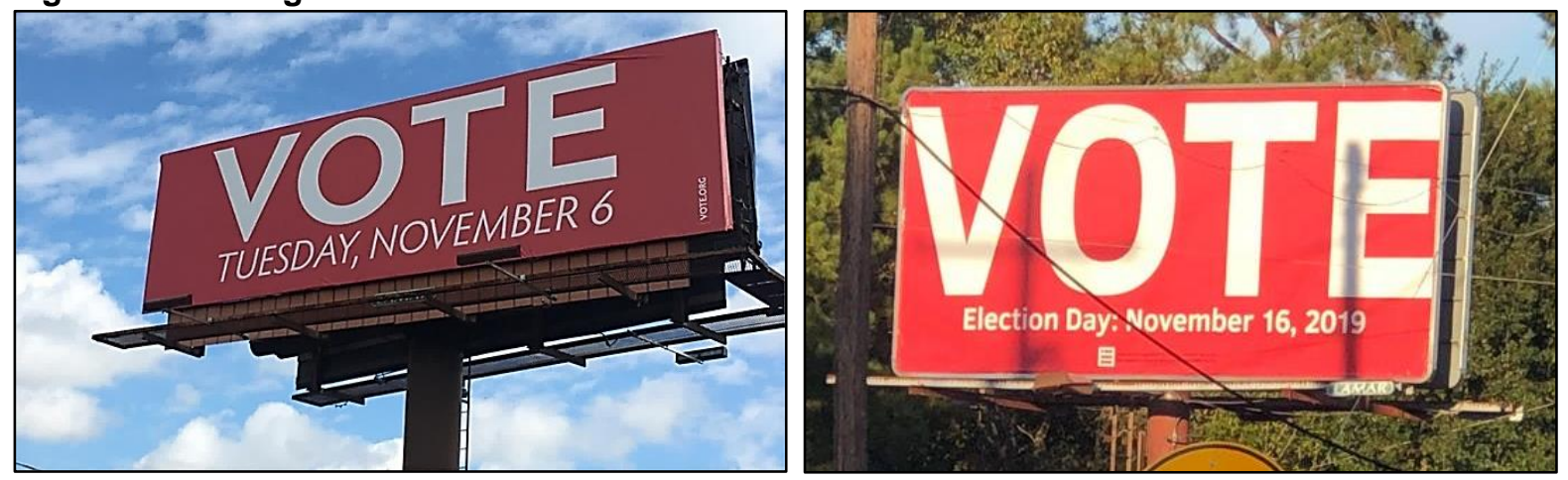

\section{Figure 3. Fishnet Random Assignment for Virginia}

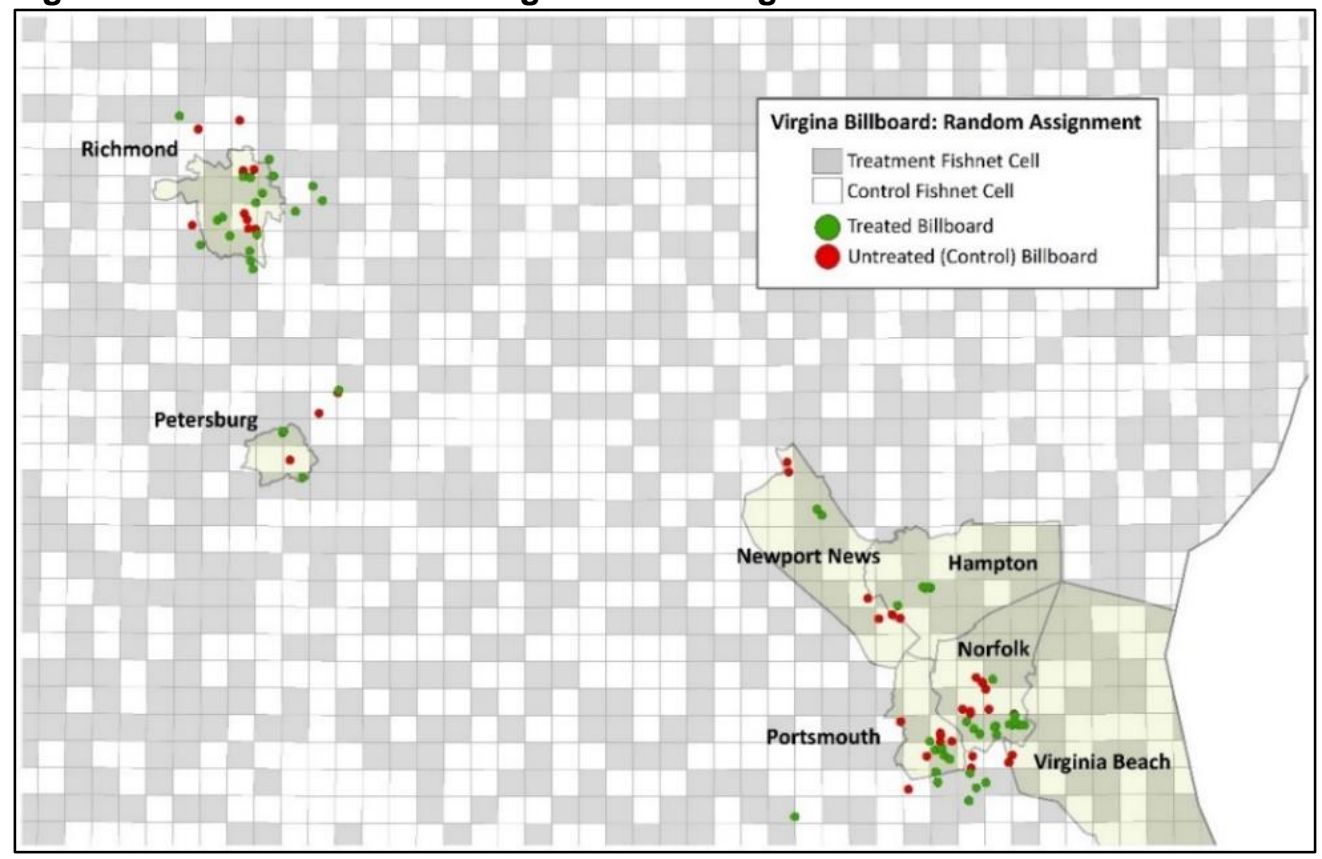

The effect of the billboards is assessed based on comparing individual-level voter turnout in treatment cells and control cells. ${ }^{3}$ Those who live near billboard may be systematically different than those who do not live near billboards. On average, areas with SPOE billboards are likely to be more

\footnotetext{
3 Turnout data was obtained via Catalist.
} 
commercial and industrial (and less residential) and have more lower-income residents than areas without billboards. As such, it is important to compare among areas with billboards. This experiment does this by restricting the analysis to registered voters that reside in the control and treatment cells. Similarly, the analysis is constrained to billboards available at the commencement of the experiment rather than all billboards because unavailable billboards may be in places systematically different than those available for purchase.

An alternative to using the fishnet boundaries for random assignment would have been to use existing political (e.g. city) or Census boundaries (e.g. tracts). However, the fishnetting procedure has notable advantages. Billboards are along roads and roads often serve as geographic boundaries for political and Census divisions. This leads to two problems. First, it means that billboards are more likely to fall along the edge of a Census boundary, potentially obscuring its effect. Second, billboards are often on both sides of the road (facing oncoming traffic). When Census boundaries split a road down the middle (as they frequently do), this can lead to one side of the road getting a treatment billboard and one side of the road getting the control billboard, which may also obscure the effect. While both of these problems can still occur with the fishnetting procedure, it is going to occur less often and in random ways.

This research design should be biased to under-estimate the effect of billboards on turnout. The design relies on an intent-to-treat (ITT) strategy because actual exposure is unknowable. Exposure and compliance in the treatment cells is less than 100\% (not everyone in the cell actually sees the billboard) and exposure/compliance to the treatment in the control cells is greater than $0 \%$ (people who live in the control cells may still see a treatment billboard in a treatment cell). This situation makes it virtually impossible to over-estimate (and very likely to under-estimate) the effect of the mobilization billboards by reducing the likely difference between the groups: treatment cells do not capture the full effect (if there is one) and control cells may show an effect from exposure to treatment outside the cell.

Table 2 describes four characteristics for each of the research areas across treatment and control fishnet cells: number of fishnet cells, number of billboards, total registered voters, and average registered voters per cell. The number of cells analyzed for Mississippi reflects a substantial reduction from the original plan. Following an error by the billboard vendor, Vote.org was provided with compensatory billboards - that did not conform to the random assignment strategy - throughout the Jackson, MS 
metropolitan area. This forced the elimination of the Jackson region (which had 45 treatment billboards and 125 control billboards) and from the analysis. The consequences of this reduction are discussed below.

Table 2. Research Area Descriptive Statistics: Treatment v. Control

\begin{tabular}{l|l|l|l|l|l|l|l|l}
\hline \multirow{2}{*}{} & \multicolumn{2}{|c|}{$\begin{array}{c}\text { Number of Fishnet } \\
\text { Cells }\end{array}$} & \multicolumn{2}{c|}{ Number of Billboards } & \multicolumn{2}{c|}{ Total Registered Voters } & \multicolumn{2}{c}{$\begin{array}{c}\text { Avg Registered Voters } \\
\text { Per Cell }\end{array}$} \\
\cline { 2 - 10 } & Treatment & Control & Treatment & Control & Treatment & Control & Treatment & Control \\
\hline Louisiana & 27 & 17 & 44 & 31 & 376,923 & 261,394 & $13,960.11$ & $15,376.12$ \\
\hline Virginia & 32 & 22 & 66 & 45 & 445,296 & 306,898 & $13,915.50$ & $13,949.91$ \\
\hline Mississippi & 35 & 25 & 65 & 47 & 166,138 & 113,940 & $4,746.80$ & $4,557.60$ \\
\hline Kentucky & 3 & 5 & 32 & 19 & 52,609 & 87,702 & $17,536.33$ & $17,540.40$ \\
\hline Combined & 97 & 69 & 207 & 142 & $1,040,966$ & 769,934 & $10,731.61$ & $11,158.46$ \\
\hline $\begin{array}{l}\text { Combined } \\
\text { (Excluding MS) }\end{array}$ & 62 & 44 & 142 & 95 & 874,828 & 655,994 & $14,110.13$ & $14,908.95$ \\
\hline
\end{tabular}

Table 3 compares treatment and control group cells for variables that are typically associated with voter turnout (Verba, Schlozman, and Brady 1995). ${ }^{4}$ These include voter history, sex (female), race (white), age, and three census variables (median income, percent white, and population density in the observation's Census block). ${ }^{5}$ Given the large N, it is not surprising that, despite the randomization, there are some statistically significant differences between control and treatment cells, even if those differences are quite small. Notably, voter history - the most statistically powerful variable of these - does not show a significant difference between treatment and control cells. Nevertheless, we control for all these variables in the models to reduce the impact of cell-to-cell differences on the turnout effect.

Table 3. Control Variable Difference of Means Tests (Cell Means)

\begin{tabular}{|c|c|c|c|c|c|c|c|}
\hline & & MS & LA & VA & KY & Combined & $\begin{array}{c}\text { Combined } \\
\text { (No MS) }\end{array}$ \\
\hline \multirow{3}{*}{$\begin{array}{l}\text { Voter } \\
\text { History }\end{array}$} & Control Mean & 1.69 & 1.63 & 1.63 & 1.32 & 1.59 & 1.59 \\
\hline & Treatment Mean & 1.63 & 1.63 & 1.59 & 1.30 & 1.59 & 1.59 \\
\hline & Difference (T-C) & $0.06^{\star \star}$ & 0.00 & $-0.04^{\star *}$ & $-0.02^{*}$ & 0.00 & 0.00 \\
\hline & & MS & LA & VA & KY & Combined & $\begin{array}{c}\text { Combined } \\
\text { (No MS) }\end{array}$ \\
\hline \multirow{3}{*}{$\begin{array}{l}\text { Sex } \\
\text { (Female) }\end{array}$} & Control Mean & 0.59 & 0.57 & 0.56 & 0.55 & 0.57 & 0.56 \\
\hline & Treatment Mean & 0.59 & 0.57 & 0.57 & 0.57 & 0.57 & 0.57 \\
\hline & Difference (T-C) & 0.00 & 0.00 & $0.01^{* *}$ & $0.02^{* *}$ & $0.00^{* *}$ & $0.01^{* *}$ \\
\hline
\end{tabular}

${ }^{4}$ Variables were restricted to those made available by Catalist - the data provider - and Census data.

${ }^{5}$ Voter history is measured as the number of elections the registered voter voted in going back to the 2016 primary. 


\begin{tabular}{|c|c|c|c|c|c|c|c|}
\hline & & MS & LA & VA & KY & Combined & $\begin{array}{c}\text { Combined } \\
\text { (No MS) }\end{array}$ \\
\hline \multirow{3}{*}{$\begin{array}{l}\text { Race } \\
\text { (White) }\end{array}$} & Control Mean & 0.36 & 0.39 & 0.47 & 0.45 & 0.43 & 0.44 \\
\hline & Treatment Mean & 0.30 & 0.42 & 0.42 & 0.35 & 0.41 & 0.42 \\
\hline & Difference (T-C) & $-0.06^{* *}$ & $0.03^{* *}$ & $-0.05^{* *}$ & $-0.1^{* *}$ & $-0.03^{* *}$ & $-0.02^{* *}$ \\
\hline & & MS & LA & VA & KY & Combined & $\begin{array}{c}\text { Combined } \\
\text { (No MS) }\end{array}$ \\
\hline \multirow{3}{*}{ Age } & Control Mean & 55.01 & 49.06 & 48.32 & 47.57 & 49.01 & 48.49 \\
\hline & Treatment Mean & 54.75 & 49.52 & 46.64 & 47.76 & 48.50 & 47.92 \\
\hline & Difference (T-C) & -0.26 & $0.45^{\star *}$ & $-1.68^{\star *}$ & 0.19 & $-0.51^{* *}$ & $-0.57^{\star *}$ \\
\hline & & MS & LA & VA & KY & Combined & $\begin{array}{c}\text { Combined } \\
\text { (No MS) }\end{array}$ \\
\hline \multirow{3}{*}{$\begin{array}{l}\text { Median } \\
\text { Income }\end{array}$} & Control Mean & 29707.47 & 39579.98 & 48082.89 & 28008.57 & 41017.75 & 41991.61 \\
\hline & Treatment Mean & 28168.30 & 40459.64 & 44983.80 & 30016.90 & 40937.80 & 42116.96 \\
\hline & Difference (T-C) & $-1539.17^{\star *}$ & $879.66^{* *}$ & $-3099.09 * *$ & $2008.33^{\star *}$ & -79.95 & $125.35^{\star *}$ \\
\hline & & MS & LA & VA & KY & Combined & $\begin{array}{c}\text { Combined } \\
\text { (No MS) }\end{array}$ \\
\hline \multirow{3}{*}{$\begin{array}{l}\text { Percent } \\
\text { White }\end{array}$} & Control Mean & 37.98 & 42.93 & 48.24 & 42.39 & 44.81 & 45.40 \\
\hline & Treatment Mean & 33.08 & 48.23 & 44.50 & 40.62 & 44.74 & 45.82 \\
\hline & Difference (T-C) & $-4.89^{* *}$ & $5.30^{* *}$ & $-3.75^{\star *}$ & $-1.78^{\star *}$ & -0.06 & $0.42^{\star *}$ \\
\hline & & MS & LA & VA & KY & Combined & $\begin{array}{c}\text { Combined } \\
\text { (No MS) }\end{array}$ \\
\hline \multirow{3}{*}{$\begin{array}{l}\text { Population } \\
\text { Density }\end{array}$} & Control Mean & 832.20 & 3761.12 & 2521.81 & 3021.90 & 2885.55 & 3062.35 \\
\hline & Treatment Mean & 758.02 & 2978.74 & 2764.74 & 2788.65 & 2679.08 & 2856.47 \\
\hline & Difference (T-C) & $-74.18^{\star *}$ & $-782.38^{\star *}$ & $242.93^{* *}$ & $-233.25^{\star *}$ & $-206.48^{* *}$ & $-205.88^{* *}$ \\
\hline & & MS & LA & VA & KY & Combined & $\begin{array}{c}\text { Combined (No } \\
\text { MS) }\end{array}$ \\
\hline \multirow{3}{*}{$\begin{array}{l}\text { Modeled } \\
\text { Voter } \\
\text { Propensity }\end{array}$} & Control Mean & 0.47 & 0.40 & 0.40 & 0.38 & 0.41 & 0.40 \\
\hline & Treatment Mean & 0.45 & 0.41 & 0.38 & 0.38 & 0.40 & 0.39 \\
\hline & Difference (T-C) & $-0.02^{\star *}$ & 0.00 & $-0.02^{\star *}$ & 0.00 & $-0.01^{\star *}$ & $-0.01^{* *}$ \\
\hline
\end{tabular}

\section{Analysis}

To test the effect of the billboards we compare individual-level voter turnout in treatment cells and control cells. For the Virginia, Mississippi, and Kentucky elections, turnout is measured using a dichotomous variable indicating whether or not a person voted in the 2019 general election. Louisiana does not have a traditional primary-general system, rather it has a two-stage general-primary with all candidates and a general-runoff if no candidate receives $50 \%$ in the general-primary. The models presented here use the first of those two elections. ${ }^{6}$ The effect is estimated using logit regression models that control for the voter propensity variables discussed above. Models that combine research areas also

6 The duration of exposure to billboards before the general-primary in Louisiana was similar to the general elections in the other three states. The billboards were kept in place, with updated information, for the general runoff election which may change the impact of the billboards. Whether longer exposure increases the impact or leads people to no longer notice the billboards should be explored in future research. 
include state-level fixed effects.

\section{Overall Effects}

The first set of results are presented in Figure 4 as a bar graph and show the effect of the billboard treatment on the probability of individual-level turnout for each state, all states combined, and all states combined excepting Mississippi. (Complete results for all models can be found in Appendix 1.) Each bar represents the change in the probability of turnout as a result of residing in a fishnet cell with at least one treatment billboard as compared to residing in a fishnet cell with at least one control billboard. The whisker on each bar indicates the 95 percent confidence interval for the effect. When the four sites are combined, the billboard treatment increases the probability of a person voting by $.023(2.3 \%)$. To put this in context, the average person in one of our control cells had a probability of turning out in 2019 of $.184(18.4 \%)$ compared to a probability of $.203(20.3 \%)$ in one of our treatment cells. This increase is similar and possibly greater than voter mobilization effects for similar interventions.

\section{Figure 4. Treatment Effects}

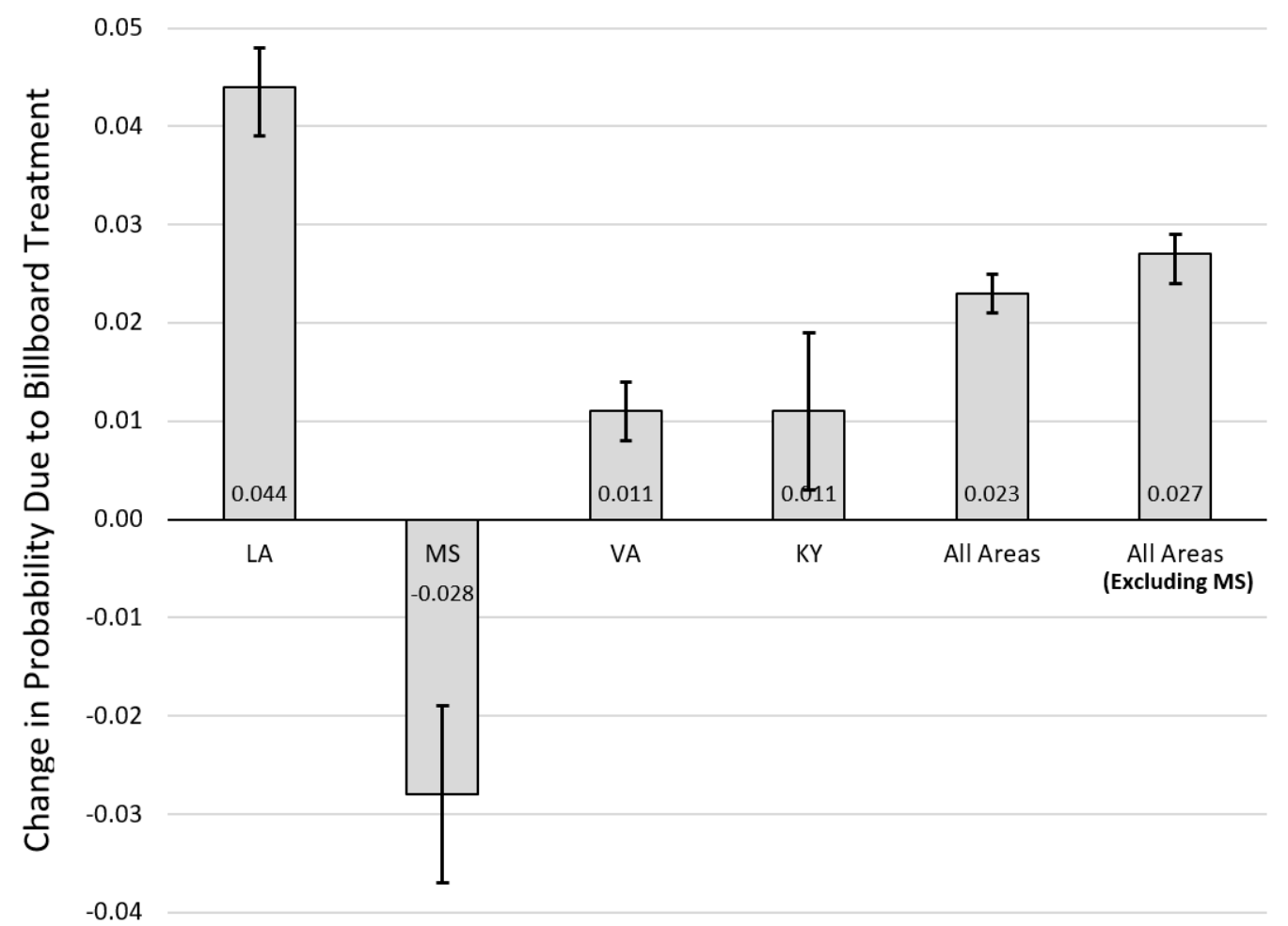


When we look at the results on a state-by-state basis, we find the effect for Mississippi is negative and significant at the $95 \%$ level. It is unlikely that non-partisan billboards that encourage turnout are actually suppressing it. While it is difficult to be confident about what is causing this negative result, it could be the result of the elimination of the Jackson-area from the analysis (discussed above). Because of this possibility, we also estimate the combined effect of the billboards excluding Mississippi and find that they produce a $.021(2.1 \%)$ increase in the probability of turning out. Among the three other areas, Louisiana had the largest effect (.028) and Virginia had the weakest effect (0.06 percentage points). Overall, Hypothesis 1 is supported by the results.

\section{Propensity Analysis}

One of the primary findings of the previous Vote.org billboard study was that the effect of billboards was most present among mid-propensity voters - voters that are neither very unlikely nor very likely to vote. This is theoretically sensible given the passive nature of billboards; they likely serve as a reminder for those who need reminding, not a stimulus to vote among those who were unmotivated to do so in the first place. ${ }^{7}$ To test this, we use a voter propensity variable that is a function of the seven control variables in the main analysis and interact it with the treatment variable. It is estimated using registered voters in the four states that do not live in a treatment or control cell so that it does not reflect the potential effect of the billboards. We then predict the propensity variable for those for who do live in a treatment or control cell. This variable represents the probability that a registered voter would vote in the 2019 election absent the presence of a billboard.

Figure 5 visualizes the interaction effect (for Louisiana, Virginia, Kentucky, and the combination of the three) by showing the change in the probability of voting due to being in a treatment cell across the range of voter propensity. (Full results can be found in Appendix 1.) In support of Hypothesis 2, we consistently find that the effect of the billboard treatment is highest among mid-propensity voters particularly among voters that would have had a probability of voting between .5 and .7 absent the presence of the treatment. This is in keeping with our first billboard study and relevant similar research.

\footnotetext{
${ }^{7}$ Considerable research has shown the conditional relationship voter-propensity has on the effect of mobilization treatments; see, for example Panagopoulos (2011).
} 


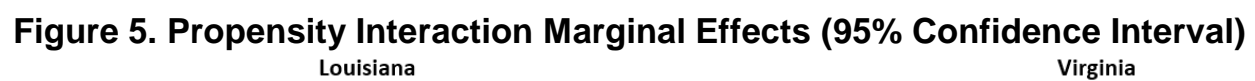
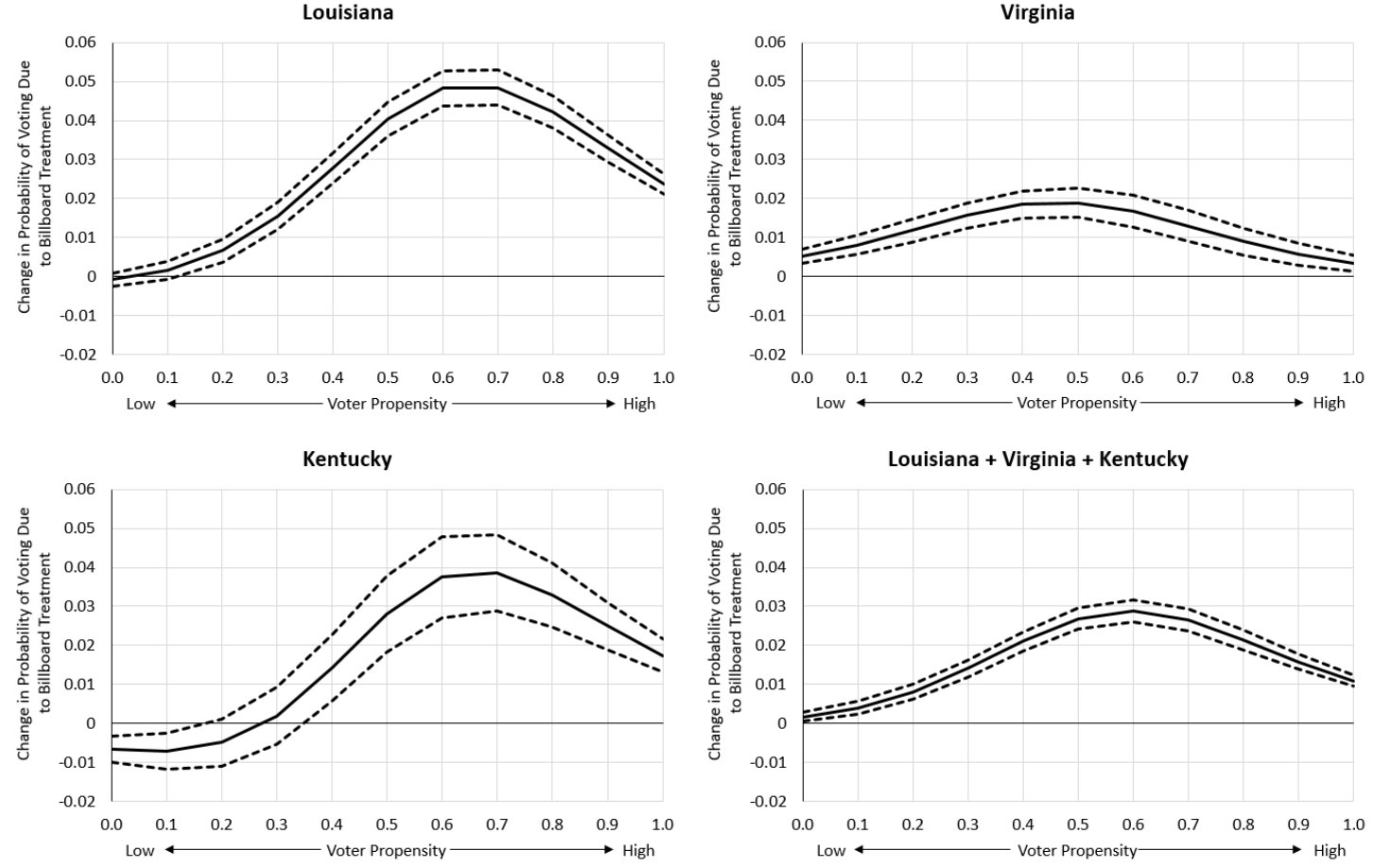

\section{Dosage and Distance}

The theoretical expectation was that exposure to more treatment billboards (dosage) and proximity to a treatment billboard would increase the effect of treatment. This was tested by estimating models that interact the treatment variable with the dosage and distance variables. Our results here present something of a puzzle and we note that neither dosage nor distance was randomly assigned so caution is warranted when making inferences. We first find that, contrary to the expectation in Hypothesis 3 , the dosage interaction indicates that a higher dosage is associated with a lower probability of turnout in treatment cells. These results do not indicate that more billboards makes the overall effect negative, just that among treated cells there is a slightly weaker effect in the higher dosage cells. The strongest predictors of both dosage and proximity to a billboard are variables that are associated with very low voter turnout (high block-group level unemployment, high poverty and low block-group level marriage). Thus, the population with higher dosage has a lower likelihood of being motivated to vote, so the reminder mechanism of a billboard may not be as effective. It could simply be that even with our randomization and controls for voter propensity, the low motivation to turnout in high dosage cells is not fully accounted for in the statistical model. 
On the other hand, we do find evidence to support Hypothesis 4 that those who live closer to a treatment billboard will be more likely to vote. ${ }^{8}$ This effect is graphed in the left panel of Figure 6 , for which we note three things. First, those living right next to a treatment billboard were more likely to turnout than someone living right next to a control billboard. Second, there is a slight negative effect for the treatment cells such that living farther away from a voter mobilization billboard is associated with a weaker treatment effect. And third, there is a positive effect for the control cells such that living farther from a billboard is associated with a higher probability of turnout - given what we know about the people that tend to live very close to a billboard (especially multiple billboards) it is not surprising that those who live far from billboards have a higher average probability of voting. The right panel of Figure 6 shows the effect of distance for cells with only one billboard (59 of the 106 non-Mississippi cells). Notably, the effect of distance on the treatment effect is stronger in these cells. In certain respects, this is a "cleaner" test of the distance hypothesis because the effect of distance is not being confounded by the presence of billboards at array of different distances.

\section{Figure 6. Distance Interaction Marginal Effects (95\% Confidence Interval)}
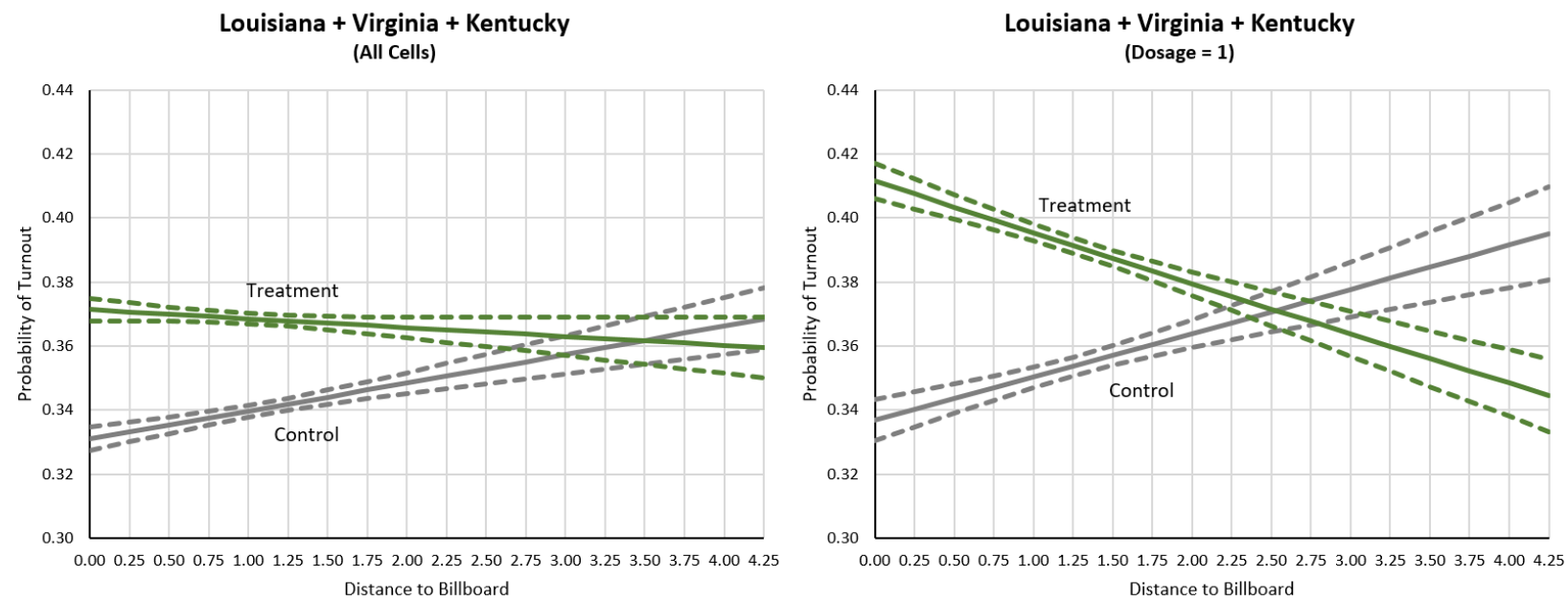

\section{Discussion}

The results of this study point to billboards having a positive impact on voter turnout, particularly

\footnotetext{
${ }^{8}$ Note that for 3-mile by 3-mile cells that farthest a person can be from a billboard in their cell is 4.24 miles. Additional one-billboard cell analyses also suggest that this relationship is curvilinear with the effect peaking for people who live about .5 to 1 mile from a billboard then declining.
} 
among mid-propensity voters. And the research design is likely under-estimating effects because we are only able test turnout within the fishnet cells when billboards likely have a substantially greater geographic reach. Caution in making generalized inferences is still warranted. We emphasize that caution on three accounts, in particular. First, the way in which billboards are observed makes the determination of a precise effect difficult. The intent-to-treat approach simply cannot guarantee that subjects in treatment cells were actually treated (saw a billboard). Second, the results for Mississippi, which ran counter to expectation, emphasize the need to avoid over-generalizing the findings. The Mississippi result may well be a function of the elimination of Jackson from the research areas or an outlier randomization, but it could also be an indication that billboards are not as effective as the rest of the study suggests. And third, the study raised some questions about how billboard dosage (the number of billboards in a given space) functions. Understanding dosage is important because it can allow for a more efficient purchasing strategy - one that minimizes cost and maximizes effectiveness.

Follow-up research could yield insight into some of the open questions from this analysis and offer more insight into billboard effectiveness. For example, different approaches to boundary randomization could be considered. The use of 3-mile by 3-mile fishnet cells makes a consistent distance-based assumption about the effect of billboards. Of course, billboard effects are not actually constrained by these imposed boundaries and this may have substantially blurred the difference between control and treatment areas. One alternative is to vary the size of the fishnet cells either within or across research sites. Another is to utilize a strategy where treatment areas and control areas are in different parts of a state so as to substantially reduce the amount of cross-contamination between treatment and control cells.

In Politics on Display (2019), Makse, Minkoff, and Sokhey find evidence that neighborhood campaign yard signs provoke a number of positive and negative emotions including anxiety, pride, and anger. Non-partisan mobilization signage, like the Vote.org billboards, does not take sides and is not attached to specific people. But it is hardly a stretch to think they too elicit emotional responses. It is less likely that they illicit negative responses from average passers-by and it is even possible that they do something more than remind people to vote, they may offer a tiny jolt of positivity toward American democracy. Such emotional responses are likely contextualized within the broader world of billboard 
advertising, which is not typically regarded as a pleasant site. They add little aesthetically to the visual environment, often obstructing good or benign views with pictures of hamburgers and personal injury lawyers. Vote.org's effort to utilize billboards to promote voter turnout in the 2018 and 2019 elections might even be seen as a kind of reprieve from this. We should want democracy to be a part of our physical environment, to see it in places outside internet browsers and television screens. 


\section{Appendix 1. Complete Models}

\begin{tabular}{|c|c|c|c|c|c|c|c|c|}
\hline \multicolumn{9}{|c|}{ Primary Logit Models (By State) } \\
\hline \multirow[b]{2}{*}{ DV: Voter Turnout } & \multicolumn{2}{|c|}{ LA } & \multicolumn{2}{|c|}{ MS } & \multicolumn{2}{|c|}{ VA } & \multicolumn{2}{|c|}{ KY } \\
\hline & Coef & SE & Coef & SE & Coef & SE & Coef & SE \\
\hline Billboard Treatment & $0.19^{\star \star \star}$ & $(0.01)$ & $-0.12^{\star \star *}$ & $(0.02)$ & $0.05^{\star * \star}$ & $(0.01)$ & $0.05^{\star *}$ & $(0.02)$ \\
\hline Voter History & $1.06^{\star \star *}$ & $(0.00)$ & $1.35^{\star \star *}$ & $(0.01)$ & $1.24^{\star * *}$ & $(0.00)$ & $1.30^{* \star *}$ & $(0.01)$ \\
\hline Female & $-0.04^{\star \star \star}$ & $(0.01)$ & -0.04 & $(0.02)$ & -0.01 & $(0.01)$ & $0.05^{*}$ & $(0.02)$ \\
\hline White & $0.09^{\star \star \star}$ & $(0.01)$ & $-0.20^{\star \star \star}$ & $(0.02)$ & $-0.09^{\star \star \star}$ & $(0.01)$ & $-0.06^{*}$ & $(0.02)$ \\
\hline Age & $0.02^{\star \star \star}$ & $(0.00)$ & $0.01^{* * \star}$ & $(0.00)$ & $0.01^{* * *}$ & $(0.00)$ & $0.01^{* \star \star}$ & $(0.00)$ \\
\hline Block Group Median Income & $0.00^{\star \star \star}$ & $(0.00)$ & -0.00 & $(0.00)$ & $0.00^{\star * \star}$ & $(0.00)$ & $0.00^{\star \star \star}$ & $(0.00)$ \\
\hline Block Group Percent White & 0.00 & $(0.00)$ & $0.00^{* *}$ & $(0.00)$ & $0.00^{*}$ & $(0.00)$ & -0.00 & $(0.00)$ \\
\hline Tract Population Density & $-0.00^{\star \star *}$ & $(0.00)$ & $-0.00^{* \star *}$ & $(0.00)$ & $0.00^{\star * *}$ & $(0.00)$ & $0.00^{* \star \star}$ & $(0.00)$ \\
\hline Constant & $-3.53^{\star \star *}$ & $(0.02)$ & $-2.76^{* * *}$ & $(0.05)$ & $-3.44^{\star \star *}$ & $(0.02)$ & $-3.10^{\star \star \star}$ & $(0.05)$ \\
\hline $\begin{array}{l}\mathrm{N} \\
\text { Pseudo } \mathrm{R}^{2}\end{array}$ & $\begin{array}{l}394,057 \\
0.35\end{array}$ & & $\begin{array}{l}87,661 \\
0.36\end{array}$ & & $\begin{array}{l}487,816 \\
0.29\end{array}$ & & $\begin{array}{l}95,429 \\
0.39\end{array}$ & \\
\hline
\end{tabular}

${ }^{*} p<0.05,{ }^{* *} p<0.01{ }^{* * *} p<0.001$

\begin{tabular}{|c|c|c|c|c|}
\hline \multicolumn{5}{|c|}{ Primary Logit Models (States Combined) } \\
\hline \multirow[b]{2}{*}{ DV: Voter Turnout } & \multicolumn{2}{|c|}{$L A+V A+K Y+M S$} & \multicolumn{2}{|c|}{$L A+V A+K Y$} \\
\hline & Coef & SE & Coef & SE \\
\hline Billboard Treatment & $0.10^{* * \star}$ & $(0.01)$ & $0.12^{\star \star \star}$ & $(0.01)$ \\
\hline Voter History & $1.18^{* * *}$ & $(0.00)$ & $1.16^{\star * *}$ & $(0.00)$ \\
\hline Female & $-0.02^{* *}$ & $(0.01)$ & $-0.02^{* *}$ & $(0.01)$ \\
\hline White & $-0.04^{* * *}$ & $(0.01)$ & $-0.03^{* * *}$ & $(0.01)$ \\
\hline Age & $0.01^{* \star *}$ & $(0.00)$ & $0.01^{* * *}$ & $(0.00)$ \\
\hline Block Group Median Income & $0.00^{* \star *}$ & $(0.00)$ & $0.00^{* * *}$ & $(0.00)$ \\
\hline Block Group Percent White & $0.00^{* \star *}$ & $(0.00)$ & $0.00^{* * *}$ & $(0.00)$ \\
\hline Tract Population Density & $-0.00^{* * *}$ & $(0.00)$ & $-0.00^{* * *}$ & $(0.00)$ \\
\hline KY (LA Excluded) & $-0.35^{\star \star \star}$ & $(0.01)$ & $-0.35^{\star \star *}$ & $(0.01)$ \\
\hline VA (LA Excluded) & $-0.34^{* * *}$ & $(0.01)$ & $-0.34^{* \star *}$ & $(0.01)$ \\
\hline MS (LA Excluded) & $-0.05^{\star * *}$ & $(0.01)$ & & \\
\hline Constant & $-3.07^{\star * *}$ & $(0.01)$ & $-3.09^{* * *}$ & $(0.01)$ \\
\hline $\mathrm{N}$ & $1,064,963$ & & 977,302 & \\
\hline Pseudo $\mathrm{R}^{2}$ & 0.33 & & 0.33 & \\
\hline
\end{tabular}

${ }^{*} p<0.05,{ }^{* *} p<0.01{ }^{* * *} p<0.001$ 


\begin{tabular}{|c|c|c|}
\hline \multicolumn{3}{|c|}{$\begin{array}{c}\text { Voter Propensity Logit Model } \\
\text { (Non-Experimental Cells) }\end{array}$} \\
\hline DV: Voter Turnout & Coef & SE \\
\hline Voter History & $1.10^{* \star \star}$ & $(0.00)$ \\
\hline Female & $-0.06^{\star \star *}$ & $(0.00)$ \\
\hline White & $0.11^{* * *}$ & $(0.00)$ \\
\hline Age & $0.01^{* * *}$ & $(0.00)$ \\
\hline Block Group Median Income & $-0.00^{* * *}$ & $(0.00)$ \\
\hline Block Group Percent White & $0.00^{\star * *}$ & $(0.00)$ \\
\hline Tract Population Density & $-0.00^{* * *}$ & $(0.00)$ \\
\hline KY (LA Excluded) & $-0.05^{\star \star \star}$ & $(0.00)$ \\
\hline VA (LA Excluded) & $-0.44^{* * *}$ & $(0.00)$ \\
\hline MS (LA Excluded) & $-0.35^{\star * *}$ & $(0.00)$ \\
\hline Constant & $-2.71^{\star \star \star}$ & $(0.01)$ \\
\hline $\mathrm{N}$ & $8,756,758$ & \\
\hline Pseudo $\mathrm{R}^{2}$ & 0.28 & \\
\hline
\end{tabular}

\begin{tabular}{|c|c|c|c|c|c|c|c|c|}
\hline \multicolumn{9}{|c|}{ Propensity Logit Interaction Models } \\
\hline \multirow[b]{2}{*}{ DV: Voter Turnout } & \multicolumn{2}{|c|}{$L A+V A+K Y$} & \multicolumn{2}{|c|}{ LA } & \multicolumn{2}{|c|}{ VA } & \multicolumn{2}{|c|}{$\mathbf{K Y}$} \\
\hline & Coef & SE & Coef & SE & Coef & SE & Coef & SE \\
\hline Billboard Treatment & $0.03^{* *}$ & $(0.01)$ & -0.02 & $(0.02)$ & $0.09^{\star \star \star}$ & $(0.02)$ & $-0.14^{* \star *}$ & $(0.04)$ \\
\hline Propensity & $5.38^{* * *}$ & $(0.02)$ & $5.21^{* * *}$ & $(0.02)$ & $5.49^{\star \star \star}$ & $(0.02)$ & $5.70^{\star * \star}$ & $(0.04)$ \\
\hline Treatment $\mathrm{X}$ Propensity & $0.15^{\star \star \star}$ & $(0.02)$ & $0.36^{\star \star *}$ & $(0.03)$ & -0.02 & $(0.03)$ & $0.51^{\star \star \star}$ & $(0.07)$ \\
\hline Constant & $-2.79^{* * *}$ & $(0.01)$ & $-2.90^{\star * \star}$ & $(0.01)$ & $-2.72^{\star * *}$ & $(0.01)$ & $-2.90^{\star \star *}$ & $(0.02)$ \\
\hline $\begin{array}{l}\mathrm{N} \\
\text { Pseudo } \mathrm{R}^{2}\end{array}$ & $\begin{array}{l}977,302 \\
0.32\end{array}$ & & $\begin{array}{l}394,057 \\
0.35\end{array}$ & & $\begin{array}{l}487,816 \\
0.28\end{array}$ & & $\begin{array}{l}95,429 \\
0.38\end{array}$ & \\
\hline
\end{tabular}

${ }^{*} p<0.05,{ }^{* *} p<0.01{ }^{* * *} p<0.001$ 


\begin{tabular}{|c|c|c|c|c|c|c|c|c|}
\hline \multicolumn{9}{|c|}{ Dosage \& Distance Interaction Logit Models } \\
\hline \multirow[b]{2}{*}{ DV: Voter Turnout } & \multicolumn{2}{|c|}{$L A+V A+K Y$} & \multicolumn{2}{|c|}{ LA } & \multicolumn{2}{|c|}{ VA } & \multicolumn{2}{|c|}{ KY } \\
\hline & Coef & SE & Coef & SE & Coef & SE & Coef & SE \\
\hline Billboard Treatment & $0.22^{\star \star \star}$ & $(0.01)$ & $0.41^{\star \star \star}$ & $(0.03)$ & $0.18^{\star \star \star}$ & $(0.02)$ & $0.32^{\star \star \star}$ & $(0.06)$ \\
\hline Dosage & $0.01^{\star \star}$ & $(0.00)$ & $-0.02^{\star \star \star}$ & $(0.01)$ & $0.02^{\star \star \star}$ & $(0.01)$ & $0.01^{*}$ & $(0.00)$ \\
\hline Dosage $X$ Treatment & $-0.02^{* * *}$ & $(0.00)$ & $-0.05^{\star * *}$ & $(0.01)$ & $-0.03^{\star \star *}$ & $(0.01)$ & $-0.02^{* \star *}$ & $(0.00)$ \\
\hline Distance & $0.04^{\star \star *}$ & $(0.01)$ & $0.06^{\star \star *}$ & $(0.01)$ & $0.06^{\star \star \star}$ & $(0.01)$ & $0.10^{\star \star *}$ & $(0.02)$ \\
\hline Treatment $\mathrm{X}$ Distance & $-0.05^{\star * *}$ & $(0.01)$ & $-0.12^{\star \star \star}$ & $(0.01)$ & $-0.06^{\star \star *}$ & $(0.01)$ & -0.01 & $(0.04)$ \\
\hline Voter History & $1.16^{\star * *}$ & $(0.00)$ & $1.06^{\star \star \star}$ & $(0.00)$ & $1.24^{\star * *}$ & $(0.00)$ & $1.30^{\star \star *}$ & $(0.01)$ \\
\hline Female & $-0.02^{* *}$ & $(0.01)$ & $-0.04^{* * *}$ & $(0.01)$ & -0.01 & $(0.01)$ & $0.05^{*}$ & $(0.02)$ \\
\hline White & $-0.03^{* * *}$ & $(0.01)$ & $0.09^{* * *}$ & $(0.01)$ & $-0.09^{* * *}$ & $(0.01)$ & $-0.07^{* *}$ & $(0.02)$ \\
\hline Age & $0.01^{* * *}$ & $(0.00)$ & $0.02^{* \star *}$ & $(0.00)$ & $0.01^{* * *}$ & $(0.00)$ & $0.01^{* * *}$ & $(0.00)$ \\
\hline Block Group Median Income & $0.00^{\star * *}$ & $(0.00)$ & $0.00^{* * *}$ & $(0.00)$ & $0.00^{* * *}$ & $(0.00)$ & $0.00^{* * *}$ & $(0.00)$ \\
\hline Block Group Percent White & $0.00^{\star * \star}$ & $(0.00)$ & $0.00^{*}$ & $(0.00)$ & $0.00^{*}$ & $(0.00)$ & $-0.00^{* *}$ & $(0.00)$ \\
\hline Tract Population Density & $-0.00^{* * *}$ & $(0.00)$ & $-0.00^{* * *}$ & $(0.00)$ & $0.00^{* * *}$ & $(0.00)$ & $0.00^{* * *}$ & $(0.00)$ \\
\hline KY (LA Excluded) & $-0.37^{\star \star \star}$ & $(0.01)$ & & & & & & \\
\hline VA (LA Excluded) & $-0.35^{\star \star \star}$ & $(0.01)$ & & & & & & \\
\hline Constant & $-3.13^{* * *}$ & $(0.02)$ & $-3.55^{\star \star *}$ & $(0.03)$ & $-3.54^{* * *}$ & $(0.03)$ & $-3.17^{* \star \star}$ & $(0.05)$ \\
\hline $\mathrm{N}$ & 977,302 & & 394,057 & & 487,816 & & 95,429 & \\
\hline Pseudo $\mathrm{R}^{2}$ & 0.33 & & 0.35 & & 0.29 & & 0.39 & \\
\hline
\end{tabular}

${ }^{*} p<0.05,{ }^{* *} p<0.01{ }^{* * *} p<0.001$

\begin{tabular}{|c|c|c|c|c|c|c|c|c|}
\hline \multicolumn{9}{|c|}{ Distance Interaction Logit Models (Cell Billboard Dosage $=1$ ) } \\
\hline \multirow[b]{2}{*}{ DV: Voter Turnout } & \multicolumn{2}{|c|}{$\mathrm{LA}+\mathrm{VA}+\mathrm{KY}$} & \multicolumn{2}{|c|}{ LA } & \multicolumn{2}{|c|}{ VA } & \multicolumn{2}{|c|}{$\mathrm{KY}$} \\
\hline & Coef & SE & Coef & SE & Coef & SE & Coef & SE \\
\hline Billboard Treatment & $0.32^{\star \star \star}$ & $(0.02)$ & $0.26^{\star \star \star}$ & $(0.03)$ & $0.29^{* \star *}$ & $(0.03)$ & $0.48^{\star \star \star}$ & $(0.10)$ \\
\hline Distance & $0.06^{\star \star \star}$ & $(0.01)$ & 0.02 & $(0.01)$ & $0.07^{* * *}$ & $(0.02)$ & $0.13^{* *}$ & $(0.04)$ \\
\hline Treatment $X$ Distance & $-0.13^{* \star *}$ & $(0.01)$ & $-0.05^{\star \star}$ & $(0.02)$ & $-0.16^{\star \star *}$ & $(0.02)$ & -0.11 & $(0.06)$ \\
\hline Voter History & $1.16^{\star \star \star}$ & $(0.00)$ & $1.08^{\star * \star}$ & $(0.00)$ & $1.25^{\star \star *}$ & $(0.01)$ & $1.19^{* \star *}$ & $(0.01)$ \\
\hline Female & $-0.03^{* *}$ & $(0.01)$ & $-0.04^{* *}$ & $(0.01)$ & $-0.02^{*}$ & $(0.01)$ & 0.03 & $(0.03)$ \\
\hline White & $-0.05^{* * *}$ & $(0.01)$ & $0.04^{\star *}$ & (0.02) & $-0.12^{* * *}$ & $(0.01)$ & -0.06 & $(0.04)$ \\
\hline Age & $0.02^{\star \star \star}$ & $(0.00)$ & $0.02^{\star \star \star}$ & $(0.00)$ & $0.01^{* * *}$ & $(0.00)$ & $0.00^{* * *}$ & $(0.00)$ \\
\hline Block Group Median Income & $0.00^{\star * *}$ & $(0.00)$ & $0.00^{\star * *}$ & $(0.00)$ & $0.00^{* * *}$ & $(0.00)$ & $0.00^{*}$ & $(0.00)$ \\
\hline Block Group Percent White & 0.00 & $(0.00)$ & $0.00^{*}$ & $(0.00)$ & $-0.00^{\star *}$ & $(0.00)$ & $0.00^{*}$ & $(0.00)$ \\
\hline Tract Population Density & $-0.00^{* * *}$ & $(0.00)$ & $-0.00^{* * *}$ & $(0.00)$ & $-0.00^{*}$ & $(0.00)$ & $0.00^{* * *}$ & $(0.00)$ \\
\hline KY (LA Excluded) & $-0.34^{* * *}$ & $(0.02)$ & & & & & & \\
\hline VA (LA Excluded) & $-0.37^{\star \star *}$ & $(0.02)$ & & & & & & \\
\hline Constant & $-3.26^{\star * *}$ & $(0.03)$ & $-3.63^{* * *}$ & $(0.03)$ & $-3.61^{* \star *}$ & $(0.04)$ & $-3.21^{\star * *}$ & $(0.09)$ \\
\hline $\begin{array}{l}\mathrm{N} \\
\text { Pseudo } \mathrm{R}^{2}\end{array}$ & $\begin{array}{l}451,085 \\
0.33\end{array}$ & & $\begin{array}{l}208,062 \\
0.36\end{array}$ & & $\begin{array}{l}213,979 \\
0.31\end{array}$ & & $\begin{array}{l}29,044 \\
0.35\end{array}$ & \\
\hline
\end{tabular}




\section{Bibliography}

Bergh, Johannes, DA Christensen, and Richard E. Matland. 2019. "When Is a Reminder Enough? Text Message Voter Mobilization in a European Context." Political Behavior. https://doi.org/10.1007/s11109-019-09578-1 (August 26, 2020).

Bhatti, Y, JO Dahlgaard, and JH Hansen. 2017. "How Voter Mobilization from Short Text Messages Travels within Households and Families: Evidence from Two Nationwide Field Experiments." Journal of Elections, Public Opinion and Parties 27(3). https://www.sciencedirect.com/science/article/pii/S0261379416301536 (August 26, 2020).

Bice, Daniel. 2012. "Bradley Foundation Helped Pay for 2010 Voter Fraud Signs." Milwaukee Journal Sentinel. http://archive.jsonline.com/blogs/news/176675811.html.

Bowman, Bridget. 2018. “Who's Behind the 'VOTE' Billboards Spotted in Key States.” Roll Call. https://www.rollcall.com/2018/10/31/whos-behind-the-vote-billboards-spotted-in-key-states/.

Fortenberry Jr, John L, James K Elrod, and Peter J McGoldrick. 2010. "Is Billboard Advertising Beneficial for Healthcare Organizations? An Investigation of Efficacy and Acceptability to Patients." Journal of Healthcare Management 55(2).

Frison, Steffi, Marnik G Dekimpe, Christophe Croux, and Peter De Maeyer. 2014. "Billboard and Cinema Advertising: Missed Opportunity or Spoiled Arms?" International Journal of Research in Marketing 31(4): 425-33.

Green, Donald P., Mary C. McGrath, and Peter M. Aronow. 2013. "Field Experiments and the Study of Voter Turnout." Journal of Elections, Public Opinion and Parties 23(1): 27-48.

Green, Donald P., and Lynn Vavreck. 2006. "Assessing the Turnout Effects of Rock the Vote's 2004 Television Commercials: A Randomized Field Experiment." Annual Meeting of the Midwest Political Science Association.

Krasno, Jonathan S, and Donald P Green. 2008. "Do Televised Presidential Ads Increase Voter Turnout? Evidence from a Natural Experiment." journals.uchicago.edu 70(1): 245-61. http://www.cnn.com/. (August 26, 2020).

Makse, Todd, Scott. L Minkoff, and Anand E. Sokhey. 2019. Politics on Display: Yard Signs and the Politicization of Social Spaces. Oxford University Press.

Mann, Christoopher B., and Katherine Haenschen. 2019. Vote.Org 2018 Cold SMS Voter Mobilization Program. https://drive.google.com/file/d/14agwypXmg5D1fHLsJMni3-Z9sTiuUAr4/view.

Minkoff, Scott L. 2019. Vote.Org 2018 Billboard Program Analysis for Mississippi and Maricopa County, $A Z$. https://drive.google.com/file/d/1Vz0as5u8_L9EI2PV6VZtftnRRuxlaDzn/view.

Pabst, Georgia. 2010. "Groups Protest Voter Fraud Ads." Milwaukee Journal Sentinel2. https://archive.jsonline.com/news/milwaukee/104816414.html/.

Panagopoulos, Costas. 2011. "Timing Is Everything? Primacy and Recency Effects in Voter Mobilization Campaigns." Political Behavior 33(1): 79-93.

Panagopoulos, Costas, and Shang E Ha. 2015. "Billboards and Turnout: A Randomized Field Experiment Misinformation View Project." Article in Journal of Political Marketing 14(4): 391-404.

http://dx.doi.org/10.1080/15377857.2015.1086141 (August 26, 2020). 
Papas, Rebecca K, Henrietta L Logan, and Scott L Tomar. 2004. "Effectiveness of a Community-Based Oral Cancer Awareness Campaign (United States)." Cancer Causes \& Control 15(2): 121-31.

Verba, S, K L Schlozman, and H E Brady. 1995. Voice and Equality: Civic Voluntarism in American Politics. Cambridge: Cambridge University Press.

"Voter Suppression Exists, It's Blatant, and Vote.Org Is Fighting Back." 2018. Vote.org. https://www.vote.org/blog/how-vote-org-made-billboards-a-smart-gotv-strategy/ (August 26, 2020). 